\title{
Environmental factors affecting childhood diarrheal disease among under-five children in Jamma district, South Wello zone, Northeast Ethiopia
}

\author{
Getachew Yismaw Workie ${ }^{1}$, Temesgen Yihunie Akalu² and Adhanom Gebreegziabher Baraki ${ }^{2 *}$
}

\begin{abstract}
Background: Globally, diarrhea is the leading cause of morbidity and mortality among less than 5 years old children and it contributes to the deaths of approximately one million children every year. In Ethiopia, diarrhea is the second cause of under-five mortality and morbidity. However, in the study area, studies were limited. Therefore, this study has assessed the prevalence of diarrhea and associated factors among $<5$ years of age in Jamma district, Northeast Ethiopia.

Methods: A community-based cross-sectional study was conducted from August 15 to September 15, 2017, in Jamma district, South Wello zone, northeast Ethiopia. A Systematic random sampling technique was used to select 614 households and a pretested structured questionnaire was used to collect the data. A multivariable logistic regression analysis was used to investigate factors associated with diarrheal disease. Adjusted Odds Ratio (AOR) with the corresponding 95\% Confidence Interval $(\mathrm{Cl})$ for variables with $P$-value $<0.05$ was used to show statistically significant association.
\end{abstract}

Results: In this study, the prevalence of diarrhea among under-five children was $23.1 \%$ (95\% Cl: $(19.4,26.5)$. Child's age 6 to 23 months [AOR: 2.46, 95\% Cl: $(1.49,4.05)]$, Living in rural area [AOR: 2.75, 95\% Cl: $(1.33,5.66)]$, absence of latrine [AOR: 4.80, 95\% Cl: $(2.39,9.60)]$, absence of handwashing facility [AOR: $2.45,95 \%$ Cl: $(1.53,3.93]$, unprotected drinking water source [AOR:2.68, 95\% Cl: $(1.54,4.68)]$, and Improper waste disposal practices [AOR:3.86, 95\% Cl: $(2.38$, 6.26)] were associated with diarrhea disease.

Conclusion: There was a high prevalence of diarrheal disease among children in the study area. Child age, rural residence, availability of latrine and handwashing facility, source of drinking water, and improper waste disposal were notably associated with childhood diarrheal disease. Therefore, improving handwashing practices and pure water supply, proper waste disposal including the availability of latrines would minimize the burden of diarrheal disease.

Keywords: Childhood, Diarrhea, Jamma district

\footnotetext{
* Correspondence: adsh04@gmail.com

${ }^{2}$ Department of Epidemiology and Biostatistics, Institute of Public Health,

College of Medicine and Health Sciences, University of Gondar, Gondar,

Ethiopia

Full list of author information is available at the end of the article
}

(c) The Author(s). 2019 Open Access This article is distributed under the terms of the Creative Commons Attribution 4.0 International License (http://creativecommons.org/licenses/by/4.0/), which permits unrestricted use, distribution, and reproduction in any medium, provided you give appropriate credit to the original author(s) and the source, provide a link to the Creative Commons license, and indicate if changes were made. The Creative Commons Public Domain Dedication waiver (http://creativecommons.org/publicdomain/zero/1.0/) applies to the data made available in this article, unless otherwise stated. 


\section{Background}

Globally, there are nearly 1.7 billion cases of childhood diarrhoeal disease every year [1]. Approximately $84 \%$ of the global burden of diarrheal disease is experienced by children under the age of 5 years [2]. Children of low and middle-income countries carry the highest proportion of this disease burden. In Africa diarrhea account for the largest cause of disease and death among young children and nearly 50\% of deaths due to diarrhea among young children occurs in Africa [3]. A total of five episodes of diarrhea occur every year in a child living in Africa and 800,000 deaths occur due to diarrhea and dehydration [4]. One-fourth to the threefourth proportion of childhood illness is due to diarrhea and $14 \%$ of children's outpatient visits are due to this problem. Diarrhea exposes children to several other infections by predisposing them to malnutrition. It also accounts for $16 \%$ of hospital admissions malnutrition $[5,6]$.

Several factors affect the occurrence of diarrhea; these include child's age, maternal education, household income, hygiene of feeding practices, breastfeeding status, malnutrition, personal hygiene, environmental sanitation, water availability and quality, and latrine utilization [7-9].

Evidence about the magnitude of diarrheal disease and the significant predictors in the study area was scarce, so this study was aimed to determine the prevalence and factors associated with childhood diarrheal disease.

\section{Methods}

\section{Study design and period}

A community-based cross-sectional study was conducted from August 15 to September 15, 2017.

\section{Study area and population}

Jamma district is one of the 21 districts of South Wello administrative zone found in Amhara National Regional State, Ethiopia. Based on the 2007 population and housing census, Jamma has a total estimated population of 144,409 . Of the total population, underfive children constitutes 19,784 (13.7\%) and 131,399 (90.9\%) of population lives in rural areas. The district has 6 health centers and 22 health posts. The Study populations were all households with at least one under-five child.

\section{Sample size and sampling procedure}

A final sample size of 614 was determined using the assumption of $P=0.23$ which is taken from a similar study [9], a margin of error $5 \%$, the $\mathrm{Z}$ value of 1.96 for $95 \%$ Confidence Interval (CI), design effect of 2 and 10\% contingency. Among 23 kebeles six kebeles were selected randomly and 20 gots (smaller administrative units) from a total of 60 gots in the 6 selected kebeles were randomly selected. All households that have at least one child were included in the study. In the case of the presence of more than one under- five children, lottery method was used to choose one child per household.

\section{Variable of the study}

The dependent variable, diarrhea was defined as the presence of loose or watery stool $\geq 3$ times during $24 \mathrm{~h}$ as reported by the mother/caregiver in the past 2 weeks before the survey. Independent variables like socio-demographic: family income, family size, number of children, parental education, parental occupation, marital status, sex of the child, age of child, maternal age, place of residence and religion; behavioral factors: water drawing and storage method, handwashing practice, feeding practice, and duration of breastfeeding; environmental factors: type of water source, distance of the water source, amount of daily water consumption, availability and functionality of latrine, presence of livestock in the house, and other factors like nutritional status of the children were used to assess diarrhea morbidity in the district. A water source is considered unprotected sources when there is no barrier or other structure to protect the water from contamination.

\section{Data collection procedures}

A structured questionnaire was used to collect the data. Mothers/caregivers were interviewed on the occurrence of diarrheal disease within the past 2 weeks prior to the data collection. The nutritional status of the children was determined by mid-upper arm circumference (MUAC) for children aged between 12 and 59 months. Child length was measured on lying down (recumbent) position for children under the age of 2 years and height was used for children beyond 2 years.

\section{Data management and analysis}

Data were cleaned, coded, and entered to Epi-info version 7 and transferred to SPSS for analysis. Summary measures like mean were calculated for continuous variables. Variables with $P$-value $<0.2$ were entered for multivariable analysis. Variables with $P$-value $<0.05$ with a $95 \%$ confidence interval were used to identify significant factors of diarrheal disease. The Adjusted odds ratio (AOR) was used to measure the strength of association and goodness of fit of the model was checked by Hosmer and Lemeshow test.

\section{Results}

\section{Socio-demographic characteristics}

A total of 614 households were included in the study with a response rate of $100 \%$. More than $86 \%$ of households had only one under-five child in the family and the mean family size was $4.8( \pm 1.56 \mathrm{SD})$ persons. The larger proportion of respondents $586(95.4 \%)$ were biological mothers. Of the total 565 (92\%), and 582 (94.9\%) were married and housewives, respectively. Regarding religion, 341 (55\%) were Christians. 
The mean age of the mothers/caregivers was $29.8( \pm 6.4)$ years (Table 1 ).

\section{Environmental and behavioral characteristics}

Five hundred sixty (91.2\%), had floors made of mud/sand/ dug, the majority of the households, 441 (71.8\%) had a latrine. Regarding their source of water, $388(63.2 \%)$ of households got from protected spring and pipe water. Most of the households, 337(54.9\%), dispose of waste in an open dump. There was no handwashing facility in 355 $(57.8 \%)$ of the households.

Out of 614 respondents, 584 (95.1\%) respondents have used a container with narrow opening store water. Six hundred seven (98.9\%) respondents used a covered container to fetch water. Most of the respondents, 472 (76.2\%) took water from drinking storage container by pouring (Table 2).

Child demographics, nutritional and health characteristics There were slightly more male 330 (53.7\%) children than females. The mean age of the children was 21.9 ( $\mathrm{SD} \pm$ 14.3) months. The majority of children, 346 (56.4\%), were partially breastfed (Table 3 ).

\section{Prevalence of diarrheal disease}

Findings from this study showed that 142 children had experienced diarrhea in the last 2 weeks preceding the survey, giving a prevalence of $23.1 \%$ (95\% CI, $19.4-$ $26.5 \%)$.

\section{Factors affecting childhood diarrhea}

In multivariable logistic regression child's age, residence, availability of latrine, availability of handwashing facility, source of water, and waste disposal practice were independently associated with diarrheal disease.

Children aged 6 to 23 months had 2.46 [AOR: 2.46, $95 \%$ CI $(1.49,4.05)]$ times higher odds of diarrhea compared to children less than 6 months The odds of developing diarrhea among rural children were 2.75 [AOR: 2.75 , 95\%CI: $(1.33,5.66)]$ times compared to their counterparts. Children from households with no latrine facility had 4.8 [AOR: $4.8,95 \%$ CI $(2.39,9.60)$ ] times higher odds of developing diarrhea than children from households who had latrine facilities. The odds of developing diarrhea was 2.45 [AOR: 2.45 , 95\% CI: $(1.53,3.93)$ ] times higher among children whose households had no handwashing facility compared to their counterparts. Children with unprotected drinking water source had 2.68 [AOR: $2.68,95 \%$ CI: $(1.54,4.68)]$ times higher odds of diarrhea than children with protected water sources. Children with openly dumped waste around the house had 3.86 [AOR: 3.86, 95\% CI $(2.38,6.26)]$ times higher odds of diarrhea compared to their counterparts (Table 4).
Table 1 Socioeconomic characteristics of the respondents, Jamma district, Northeast Ethiopia, 2017

\begin{tabular}{lll}
\hline Variables & Frequency & Percentage (\%) \\
\hline $\begin{array}{l}\text { Family size (persons } \\
\text { per household) }\end{array}$ & & \\
$\quad$ Less than five & 306 & 49.8 \\
$\quad$ Five and above & 308 & 50.2 \\
$\begin{array}{l}\text { Number of under } \\
\text { five children }\end{array}$ & \\
$\quad$ One & 533 & 86.8 \\
$\quad$ Two or more & 81 & 13.2 \\
Residence & & \\
Rural & 545 & 88.8 \\
Urban & 69 & 11.2
\end{tabular}

Relation of the

respondent to the child

Mother

Caregiver

Age of the mother/

caretaker (in years)

$\begin{array}{lll}<25 & 165 & 26.9 \\ 25-34 & 296 & 48.2 \\ \geq 35 & 153 & 24.9\end{array}$

Marital status of mother

$\begin{array}{lll}\text { Married } & 565 & 92\end{array}$

Single

Divorced

Widowed

Religion

Muslim

44.5

Christian

Educational level of mother

Unable to read and write

Primary

Secondary and higher

Occupation of the mother

House wife

Governmental employee

Private

Educational level of father

Unable to read and write

Primary

Secondary and above

Occupation of the father

$$
\text { Farmer }
$$


Table 2 Environmental and behavioral characteristics of respondents, Jamma district, Northeast Ethiopia, 2017

\begin{tabular}{|c|c|c|}
\hline Variables & Frequency & Percentage (\%) \\
\hline \multicolumn{3}{|l|}{$\begin{array}{l}\text { Types of roof material } \\
\text { of the living house }\end{array}$} \\
\hline Thatched & 41 & 6.7 \\
\hline Corrugated iron sheet & 573 & 93.3 \\
\hline \multicolumn{3}{|l|}{$\begin{array}{l}\text { Types of floor material } \\
\text { of the living house }\end{array}$} \\
\hline Mud/sang/dug & 560 & 91.2 \\
\hline Cement & 46 & 7.5 \\
\hline Wood & 8 & 1.3 \\
\hline \multicolumn{3}{|l|}{$\begin{array}{l}\text { Animals live with } \\
\text { family in one house }\end{array}$} \\
\hline Yes & 96 & 15.6 \\
\hline No & 518 & 84.4 \\
\hline \multicolumn{3}{|l|}{$\begin{array}{l}\text { Number of rooms } \\
\text { in the house }\end{array}$} \\
\hline One & 77 & 12.5 \\
\hline Two & 223 & 36.3 \\
\hline More than two & 314 & 51.1 \\
\hline \multicolumn{3}{|l|}{ Availability of latrine } \\
\hline Yes & 441 & 71.8 \\
\hline No & 173 & 28.2 \\
\hline \multicolumn{3}{|l|}{$\begin{array}{l}\text { Availability of } \\
\text { handwashing facility }\end{array}$} \\
\hline Yes & 259 & 42.2 \\
\hline No & 355 & 57.8 \\
\hline \multicolumn{3}{|l|}{ Main source of water } \\
\hline Protected & 388 & 63.2 \\
\hline Unprotected & 226 & 36.8 \\
\hline \multicolumn{3}{|l|}{ Distance of water source } \\
\hline$<30 \min$ & 193 & 31.4 \\
\hline$\geq 30 \mathrm{~min}$ & 421 & 69.6 \\
\hline \multicolumn{3}{|l|}{$\begin{array}{l}\text { Way of taking water } \\
\text { from container }\end{array}$} \\
\hline Pouring & 472 & 76.2 \\
\hline Dipping & 142 & 23.1 \\
\hline \multicolumn{3}{|l|}{ Site of waste disposal } \\
\hline Pit/Burn & 277 & 45.1 \\
\hline Open dump & 337 & 54.9 \\
\hline \multicolumn{3}{|l|}{ Breastfeeding status } \\
\hline No & 176 & 28.6 \\
\hline Partial & 346 & 56.4 \\
\hline Exclusive & 92 & 15 \\
\hline \multicolumn{3}{|c|}{ Child feeding methods/material } \\
\hline Hand & 295 & 48 \\
\hline Cup and spoon & 227 & 36.9 \\
\hline
\end{tabular}

Table 3 Demographic, nutritional and health characteristics of the index children in Jamma district, Northeast Ethiopia, 2017

\begin{tabular}{|c|c|c|}
\hline Variables & Frequency & Percentage (\%) \\
\hline \multicolumn{3}{|l|}{ Age of the child } \\
\hline $1-5$ months & 52 & 8.5 \\
\hline 6-23 months & 338 & 55 \\
\hline 24-59 months & 224 & 36.5 \\
\hline \multicolumn{3}{|l|}{ Sex of the child } \\
\hline Male & 330 & 53.7 \\
\hline Female & 284 & 46.3 \\
\hline \multicolumn{3}{|l|}{ Place of birth } \\
\hline Health Institution & 517 & 84.2 \\
\hline Home & 97 & 15.8 \\
\hline \multicolumn{3}{|l|}{ Birth Order } \\
\hline First & 156 & 25.4 \\
\hline Second - third & 320 & 52.1 \\
\hline Fourth and above & 138 & 22.5 \\
\hline \multicolumn{3}{|l|}{$\begin{array}{l}\text { Nutritional status } \\
\text { of the child }\end{array}$} \\
\hline Malnourished & 53 & 8.6 \\
\hline Well nourished & 561 & 91.4 \\
\hline \multicolumn{3}{|l|}{$\begin{array}{l}\text { Number of Rota } \\
\text { vaccine received }\end{array}$} \\
\hline 1 drop & 409 & 66.6 \\
\hline 2 drop & 188 & 30.6 \\
\hline 3 drop & 17 & 2.8 \\
\hline
\end{tabular}

\section{Discussion}

This study determined the magnitude of diarrhea and the factors affecting it. The 2 week prevalence of diarrhea was $23.1 \%$ and a child's age, residence, availability of latrine, availability of handwashing facility, source of water, and waste disposal practice were independently associated with diarrheal disease.

The prevalence of diarrhea in this study $(23.1 \%)$ was higher than the Ethiopian national prevalence of diarrheal disease (13\%) as reported by EDHS 2016 [10]. It is also higher than a study conducted in KeffaSheka [11], Amhara region [7], rural Tanzania [12] and Bangladesh [13]. This figure was in line with a study from northwest Ethiopia [8] and Cameroon (23.8\%) [9] However, it was lower when compared with some parts of the country (Ethiopia), which was $33.7 \%$ at Nekemte town [14], and $30.5 \%$ at Arbaminch [15]. The possible reason could be variation in the distribution of water supply, health, and other facilities across these different settings.

The odds of having diarrhea was higher among rural children than urban ones and this finding was in line with the findings in some parts of Ethiopia like Kersa, Debrebirhan town and Jabithennan [8, 16, 17]. This could be related to the wide discrepancy in the presence 
Table 4 Factors affecting diarrhea disease among children under 5 years of age, Jamma district, Northeast Ethiopia, 2017

\begin{tabular}{|c|c|c|c|c|}
\hline \multirow[t]{2}{*}{ Variables } & \multicolumn{2}{|c|}{ Diarrhea } & \multirow[t]{2}{*}{ COR (95\%) Cl } & \multirow[t]{2}{*}{$\mathrm{AOR}(95 \%) \mathrm{Cl}$} \\
\hline & Yes & No & & \\
\hline \multicolumn{5}{|l|}{ Residence } \\
\hline Rural & 116 & 429 & $2.24(1.32-3.8)$ & $2.75(1.33-5.66)^{*}$ \\
\hline Urban & 26 & 43 & 1 & 1 \\
\hline \multicolumn{5}{|l|}{ Educational level of mother } \\
\hline Unable to read and write & 49 & 343 & $2.6(1.4-4.9)$ & $1.72(0.77-3.83)$ \\
\hline Primary & 75 & 81 & $0.4(0.21-0.76)$ & $0.29(0.13-0.66)$ \\
\hline Secondary and higher & 18 & 48 & 1 & 1 \\
\hline \multicolumn{5}{|l|}{$\begin{array}{l}\text { Types of floor material } \\
\text { of the living house }\end{array}$} \\
\hline Mud/sand/dug & 120 & 440 & $3.1(1.66-5.69)$ & $2.46(0.96-6.31)$ \\
\hline Wood & 1 & 7 & $5.88(0.67-51.7)$ & $5.45(0.19-154)$ \\
\hline Cement & 21 & 25 & 1 & 1 \\
\hline \multicolumn{5}{|l|}{$\begin{array}{l}\text { Availability of latrine } \\
\text { /toilet facilities }\end{array}$} \\
\hline Yes & 130 & 311 & 1 & 1 \\
\hline No & 12 & 161 & $5.6(3.01-10.44)$ & $4.80(2.39-9.60)^{*}$ \\
\hline \multicolumn{5}{|l|}{$\begin{array}{l}\text { Availability of } \\
\text { handwashing facilities }\end{array}$} \\
\hline Yes & 94 & 165 & 1 & \\
\hline No & 48 & 307 & $3.6(2.45-5.40)$ & $2.45(1.53-3.93)^{*}$ \\
\hline \multicolumn{5}{|l|}{$\begin{array}{l}\text { Main source of } \\
\text { drinking water }\end{array}$} \\
\hline Protected & 117 & 271 & & \\
\hline Unprotected & 25 & 201 & $3.47(2.17-5.55)$ & $2.68(1.54-4.68)^{*}$ \\
\hline \multicolumn{5}{|l|}{ Site of waste disposal } \\
\hline Pit/burn & 99 & 178 & 1 & \\
\hline Open dump & 43 & 294 & $3.8(2.54-5.69)$ & $3.86(2.38-6.26)^{*}$ \\
\hline \multicolumn{5}{|l|}{$\begin{array}{l}\text { Way of taking water } \\
\text { from container }\end{array}$} \\
\hline Pouring & 126 & 346 & 1 & 1 \\
\hline Dipping & 16 & 126 & $2.9(1.64-5.0)$ & $4.0(0.86-7.90)$ \\
\hline \multicolumn{5}{|l|}{ Age of index child } \\
\hline $1-5$ months & 11 & 41 & $1.8(0.88-3.7)$ & $1.71(0.98-2.66)$ \\
\hline 6-23 months & 58 & 280 & $2.33(1.57-3.47)$ & $2.46(1.49-4.05)^{*}$ \\
\hline$\geq 24$ months & 73 & 151 & 1 & 1 \\
\hline
\end{tabular}

of infrastructures that affect the occurrence of diarrhea, these include health care, water and sanitation facilities and literacy [18].

The finding of this study showed that children aged 6 to 23 months were at high risk of developing diarrhea than children 2 years old. This finding is in agreement with other studies conducted in Arbaminch and Benishangul Gumuz, and districts of the Amhara region $[7,15,19]$. Children above the age of 6 months are at the age where they are introduced to foods other than breast milk, this may expose their undeveloped immunity to infectious agents causing diarrhea. Besides children at these ages will start to crawl, thus they may pick dirt or other contaminated objects and take to their mouth.

Open waste disposal around the house was also found to be a significant risk factor for diarrhea. This finding was in line with studies conducted in Sheko district and Kersa eastern Ethiopia [16, 20]. Open waste disposal causes the child to contact to contaminated environment 
and also creates an ideal environment for flies that carry the pathogens to water, food and food utensils.

This study found a significant association between diarrheal disease and lack of latrine which is supported by another study conducted in Derashe town [21], northwest Ethiopia [7] and Ghana [22]. The simple explanation might be that the availability of latrine reduces fecal contamination of the environment and also it reduces the chance of mechanical vectors' access to diarrhea-causing organisms thereby reducing diarrheal disease.

The finding of our study showed that the use of unprotected water sources was significantly associated with diarrheal disease. This study is consistent with the study Derashe district, Southern Ethiopia [21] and Pawi Special District in Benishangul-Gumuz Region [23]. Since unprotected sources are those with no barrier or other structure to protect the water from contamination; they can get contaminated easily and cause diarrhea while ingested. Unprotected water sources are also important source of diarrhea causing intestinal parasites like giardiasis [23].

This study can be generalized to all under-five children in Jamma district and for other areas with similar setting however; it shares the limitation of a cross-sectional study. As a result, this study may have a difficulty to show the temporal relationship between exposure and outcome variable.

\section{Conclusion}

In conclusion, the findings of this study showed that the prevalence of childhood diarrheal disease was high. So, childhood diarrheal disease remains a serious public health challenge in the study area. Living in rural areas, lack of sanitation facilities, unprotected sources of drinking water, improper waste disposal, and child age were significantly associated with childhood diarrheal disease. Therefore, improving handwashing practices and pure water supply, proper waste disposal including the building and utilizing latrines would minimize the burden of diarrheal disease.

\section{Abbreviations}

CSA: Central Statistical Agency; EDHS: Ethiopia Demographic Health Survey; ETB: Ethiopian Birr; GC: Gregorian calendar; SPSS: Statistical Package for Social Studies; WHO: World Health Organization

\section{Acknowledgments \\ Firstly, we would like to forward our kindest regards to our study participants. We extend our thanks to data collectors and supervisors without them the report will not be materialized. At last but not least, the authors would forward great thanks to the University of Gondar for the ethical approval.}

\section{Authors' contributions}

GYW conceived of the study, coordinated data collection. GYW, TYA, and AGB performed statistical analysis and drafted the manuscript. All authors have read and approved the final manuscript.

\section{Authors' information}

Getachew Yismaw has a masters degree in field epidemiology at the University of Gondar and currently, he is working at the South Wello zonal health department as a public health emergency early warning and preparedness officer.

Temesgen Yihunie has a BSC degree in Public health as a background and second degree in Epidemiology and Biostatistics; now he is teaching Epidemiology, research methodology and communicable disease control courses at the University of Gondar, Ethiopia.

Adhanom Gebreegziabher has a BSC degree in Public health as a background and second degree in Epidemiology and Biostatistics: now he is teaching Epidemiology, Research methodology and communicable disease control courses at the University of Gondar, Ethiopia.

Funding

No funding was obtained for this study.

Availability of data and materials

Data will be available from the corresponding author upon a reasonable request.

\section{Ethics approval and consent to participate}

This work has been approved by the ethical review committee of the University of Gondar, College of Medicine and Health Science, Institute of Public Health. Permission was obtained from the Jamma district health Office. Since personal identifiers are not taken only verbal consent to participate was obtained from parents/caregivers after a full description of the objective and pros and cons of participating was given for both the parents/caregivers and children; this is also accepted by the ethical review committee.

\section{Consent for publication \\ Not applicable.}

\section{Competing interests}

The authors declare that they have no competing interests.

\section{Author details}

${ }^{1}$ South Wello Zonal Health Department Public Health Emergency Early Warning and Preparedness Officer, South Wello, Ethiopia. ${ }^{2}$ Department of Epidemiology and Biostatistics, Institute of Public Health, College of Medicine and Health Sciences, University of Gondar, Gondar, Ethiopia.

Received: 24 May 2019 Accepted: 6 September 2019

Published online: 13 September 2019

\section{References}

1. World Health Organizaion. Diarrhoeal disease. 2017. Available at https:// www.who.int/news-room/fact-sheets/detail/diarrhoeal-disease. Accessed 13 Aug 2019.

2. Bartlett S. Water, sanitation and urban children: the need to go beyond "improved" provision. Children Youth Environ. 2005;15(1):115-37.

3. Walker CLF, Perin J, Aryee MJ, Boschi-Pinto C, Black RE. Diarrhea incidence in low-and middle-income countries in 1990 and 2010: a systematic review. BMC Public Health. 2012;12(1):220.

4. Woldemicael G. Diarrhoeal morbidity among young children in Eritrea: environmental and socioeconomic determinants. J Health Popul Nutr. 2001; 19(2):83-90.

5. Ketsela T, Asfaw M, Belachew C. Knowledge and practice of mothers/caretakers towards diarrhoea and its treatment in rural communities in Ethiopia. Ethiop Med J. 1991;29(4):213-24.

6. Hamer D, Simon J, Thea D, Keusch G. Childhood diarrhea in sub-Saharan Africa; 1998.

7. Azage M, Kumie A, Worku A, Bagtzoglou AC. Childhood diarrhea in high and low hotspot districts of Amhara region, Northwest Ethiopia: a multilevel modeling. J Health Popul Nutr. 2016;35(1):13.

8. Anteneh ZA, Andargie K, Tarekegn M. Prevalence and determinants of acute diarrhea among children younger than five years old in Jabithennan District, Northwest Ethiopia, 2014. BMC Public Health. 2017;17(1):99.

9. Tambe A, Nzefa L, Nicoline N. Childhood diarrhea determinants in sub-Saharan Africa: a cross sectional study of Tiko-Cameroon. Challenges. 2015;6(2):229-43.

10. CSACE I. Ethiopia Demographic and Health Survey 2016. Addis Ababa, Rockville: CSA and ICF; 2016. 
11. Tessema T, Hailu S, Anberbir S, Mitikie G. Household illness prevalence and its determinants in the under-five children. Ethiop J Health Dev. 2001;15(3):173-8.

12. Kanté $A M$, Gutierrez HR, Larsen AM, Jackson EF, Helleringer $S$, Exavery A, et al. Childhood illness prevalence and health seeking behavior patterns in rural Tanzania. BMC Public Health. 2015;15(1):951.

13. Sarker AR, Sultana M, Mahumud RA, Sheikh N, Van Der Meer R, Morton A. Prevalence and health care-seeking behavior for childhood diarrheal disease in Bangladesh. Global pediatric health 2016;3:2333794X16680901.

14. Regassa G, Birke W, Deboch B, Belachew T. Environmental determinants of diarrhea among under-five children in Nekemte town, western Ethiopia. Ethiop J Health Sci. 2008:18(2):39-45.

15. Mohammed S, Tamiru D. The burden of diarrheal diseases among children under five years of age in Arba Minch District, southern Ethiopia, and associated risk factors: a cross-sectional study. Int Sch Res Not. 2014;2014:1-7.

16. Mengistie B, Berhane $Y$, Worku A. Prevalence of diarrhea and associated risk factors among children under-five years of age in eastern Ethiopia: a crosssectional study. Open J Prev Med. 2013;3(7):446.

17. Mamo A, Hailu A. Assessment of prevalence and related factors of diarrheal diseases among under-five year's children in Debrebirehan referral hospital, Debrebirehan town, north Shoa zone, Amhara region, Ethiopia. Open Access Library J. 2014;1(01):1.

18. Watson L, Shibata T, Ansariadi MA, Nikitin I, Wilson J. Understanding modifiable risk factors associated with childhood diarrhea in an eastern Indonesian urban setting. Int J Health Promot Educ. 2015;53(1):42-54.

19. Mihrete TS, Alemie GA, Teferra AS. Determinants of childhood diarrhea among underfive children in Benishangul Gumuz regional state, north West Ethiopia. BMC Pediatr. 2014;14(1):102.

20. Gebru T, Taha M, Kassahun W. Risk factors of diarrhoeal disease in underfive children among health extension model and non-model families in Sheko district rural community, Southwest Ethiopia: comparative crosssectional study. BMC Public Health. 2014;14(1):395.

21. Godana W, Mengiste B. Environmental factors associated with acute diarrhea among children under five years of age in derashe district, southern Ethiopia. Sci J Public Health. 2013;1 (3):119-24.

22. Boadi KO, Kuitunen M. Childhood diarrheal morbidity in the Accra metropolitan area, Ghana: socio-economic, environmental and behavioral risk determinants. J Health Popul Dev Countries. 2005:7:1-13.

23. Tigabu E, Petros B, Endeshaw T. Prevalence of giardiasis and cryptosporidiosis among children in relation to water sources in selected village of Pawi Special District in Benishangul-Gumuz Region, northwestern Ethiopia. Ethiop J Health Dev. 2010;24(3):205-13.

\section{Publisher's Note}

Springer Nature remains neutral with regard to jurisdictional claims in published maps and institutional affiliations.

Ready to submit your research? Choose BMC and benefit from:

- fast, convenient online submission

- thorough peer review by experienced researchers in your field

- rapid publication on acceptance

- support for research data, including large and complex data types

- gold Open Access which fosters wider collaboration and increased citations

- maximum visibility for your research: over $100 \mathrm{M}$ website views per year

At $\mathrm{BMC}$, research is always in progress.

Learn more biomedcentral.com/submissions 